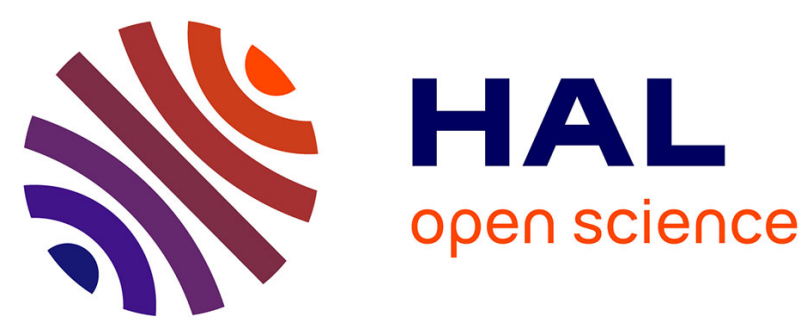

\title{
Central GABAergic innervation of the pituitary in goldfish: A radioautographic and immunocytochemical study at the electron microscope level
}

Olivier Kah, Pierrette Dubourg, Maria-Grazia Martinoli, Mohammed Rabhi, Francis Gonnet, Michel Geffard, André Calas

\section{To cite this version:}

Olivier Kah, Pierrette Dubourg, Maria-Grazia Martinoli, Mohammed Rabhi, Francis Gonnet, et al.. Central GABAergic innervation of the pituitary in goldfish: A radioautographic and immunocytochemical study at the electron microscope level. General and Comparative Endocrinology, 1987, 67 (3), pp.324-332. 10.1016/0016-6480(87)90186-9 . hal-01611439

\author{
HAL Id: hal-01611439 \\ https://hal.science/hal-01611439
}

Submitted on 5 Oct 2017

HAL is a multi-disciplinary open access archive for the deposit and dissemination of scientific research documents, whether they are published or not. The documents may come from teaching and research institutions in France or abroad, or from public or private research centers.
L'archive ouverte pluridisciplinaire HAL, est destinée au dépôt et à la diffusion de documents scientifiques de niveau recherche, publiés ou non, émanant des établissements d'enseignement et de recherche français ou étrangers, des laboratoires publics ou privés. 


\title{
Central GABAergic Innervation of the Pituitary in Goldfish: A Radioautographic and Immunocytochemical Study at the Electron Microscope Level
}

\author{
Olivier Kaf,, * Pierrette Dubourg, ${ }^{*}$ Maria-Grazia Martinoli, ${ }^{*}$ \\ Mohammed RabHi, $*$ Francis Gonnet,$\dagger$ Michel GefFard, $\neq$ and André Calas* \\ *Laboratoire de Physiologie des Interactions Cellulaires, UA CNRS 339, Talence, France; thaboratoire de \\ Physiologie des Poissons, INRA, Campus de Beaulieu, Rennes, France; and $¥$ Laboratoire de \\ Neuroimmunologie, IBCN CNRS, rue Camille Saint-Saëns, Bordeaux, France
}

Accepted April 17, 1987

\begin{abstract}
The GABAergic innervation of the goldfish pituitary was studied at the light and electron microscope levels by means of radioautography after in vitro incubation in tritiated $\gamma$-aminobutyric acid (GABA) and immunocytochemistry using antibodies against GABA. Following incubation of pituitary fragments in a medium containing tritiated GABA, a selective uptake of the tracer was observed within the digitations of the neurohypophysis. Silver grain clusters were also observed in the adenohypophyseal tissue. At the electon microscope level, this uptake was found to correspond to nerve endings containing small clear and dense-core vesicles. These labeled profiles were located mainly in neurohypophyseal digitations in close apposition with the basement membrane separating the neurohypophysis from the adenohypophysis. However, they were also encountered in direct contact with most adenohypophyseal cell types in the different lobes. These results were confirmed by immunocytochemical data demonstrating the presence of numerous GABA immunoreactive fibers in both anterior and neurointermediate lobes. They were found either in the digitations of the neurohypophysis or in the adenohypophysis in direct contact with the glandular cells with a distribution and an ultrastructural aspect similar to those observed by radioautography. These data demonstrate that the pituitary of teleosts receives a massive GABAergic innervation. Although physiological data providing a functional significance for such an innervation are lacking, the present study suggests that, as already documented in mammals, GABA may be involved in the neuroendocrine regulation of pituitary functions in teleosts. (c) 1987 Academic Press, Inc.
\end{abstract}

$\gamma$-Aminobutyric acid (GABA) is classically considered to be one of the major inhibitory neurotransmitters within the central nervous system of vertebrates. In addition, it is well documented in mammals that GABA is involved in the neuroendocrine regulations of pituitary functions either by a direct action at the level of the hypophysis or by modulating the activity of hypophysiotrophic factors at the hypothalamic level (for reviews see Racagni et al., 1982; Tappaz, 1984; McCann et al., 1984). In support of these data, significant levels of GABA and GABA transaminase activity have been detected in the anterior and neurointermediate (NIL) lobes of the pitu- itary (Racagni et al., 1979), while L-glutamate decarboxylase (GAD) activity could be measured only in the NIL (Racagni et al., 1979; Oertel et al., 1982). As a morphological support for the role of GABA in the neuroendocrine control of pituitary functions in mammals, GAD-immunoreactive (Ir) fibers were observed in close association with portal vessels of the median eminence and in the NIL of rats (Vincent $e t$ al., 1982; Oertel et al., 1982; Tappaz et al., 1983; Berod et al., 1984) and mice (Stoeckel et al., 1985). The recent introduction of antibodies against GABA itself (Seguela et al., 1984) confirms these results by the direct visualization of GABA itself 
in the median eminence-pituitary complex of rats (C. Decavel, unpublished results) and mice (Rabhi et al. 1987).

To date, there is very little information concerning the eventual participation of GABA in the regulation of pituitary func. tions in lower vertebrates. In the carp, it was shown that GABA inhibits the stressinduced elevation of cortisol (Follénius, 1977) and that $\left[{ }^{3} \mathrm{H}\right] \mathrm{GABA}$ is selectively taken up by nerve endings located in the rostral neurohypophysis $(\mathrm{NH}$; Follénius, 1972). More recently, GABA was demonstrated to be a potent inhibitor of melanocyte-stimulating hormone (MSH) secretion from the pars intermedia (PI) of amphibians, where GAD-Ir fibers could be visualized (Verburg-Van Kemenade et al., 1986).

Because of the direct innervation of its secretory cells, not only in the intermediate lobe (IL) but also in the pars distalis (PD), the pituitary of teleosts is unique among vertebrates (see Ball, 1981) and provides a model that allows the search for neurohormones and/or neurotransmitters, which, if present, are putative candidates involved in the regulation of hypophyseal functions. In the present work, we report our observations on the GABAergic innervation of the goldfish pituitary using radioautography following in vitro $\left[{ }^{3} \mathrm{H}\right] \mathrm{GABA}$ administration or immunocytochemistry of GABA itself.

\section{MATERIALS AND METHODS}

Goldfish of the common variety were collected from a local pond and were acclimated in large tanks under running water and a natural photoperiod.

Radioautography. The fish were decapitated and the rapidly dissected pituitaries were cut into three pieces and transferred in an oxygenated Ringer solution adapted for fish (see Kah et al., 1984) for a 5-min preincubation period. $\left[{ }^{3} \mathrm{H}\right] \mathrm{GABA}\left(10^{-5}\right.$ or $10^{-6} \mathrm{M}$; sp act, $30 \mathrm{Ci} / \mathrm{mmol}$; Amersham) was then added for 15 min. After washing for $5 \mathrm{~min}$, the pieces were processed for light and electron microscope radioautography as described by Kah et al. (1984). Exposure duration for light microscopy was 15-20 days and for electron microscopy was 40 days.
Immunocytochemistry. The fish were anesthetized with MS-222 (Sandoz) and either perfused with $6.25 \%$ glutaraldehyde in phosphate buffer $(0.1 \mathrm{M}, \mathrm{pH} 7.2)$ or decapitated for rapid dissection of the pituitary and immersion in the same fixative. After fixation, the tissues were washed for $3-4 \mathrm{hr}$ to remove free aldehyde and were cut at $40 \mu \mathrm{m}$ with a Vibratome. The sections were first incubated with antibodies against GABA coupled to bovine serum albumin with glutaraldehyde prepared by Dr. M. Geffard according to Seguela et al. (1984). The antiserum was routinely diluted 1:15,000 in phosphate buffer. After washing, the sections were exposed to sheep anti-rabbit peroxidase-labeled Fab fragments (Byosis) diluted 1:2000. Peroxidase activity was revealed using $0.025 \%$ diaminobenzidine (Sigma) containing hydrogen peroxide $(0.003 \%)$. Sections were then either mounted on glass slides for light microscopy or processed for electron microscopy as previously reported (Kah et al., 1986).

The specificity of the primary immune serum was checked by routine immunocytochemical controls and by competition experiments in vitro as previously described (Seguela et al., 1984). Competitors included GABA, $\beta$-alanine, glycine, taurine, glutamate, and aspartate, all coupled to lysine by glutaraldehyde.

\section{RESULTS}

Radioautography. At the light microscope level an important uptake of the tracer was noted in all parts of the pituitary, mostly overlapping the digitations of the neurohypophysis (Fig. 1). However, silver grain clusters were also detected in the adenohypophyseal tissue. At the electron microscope level, this uptake was seen to correspond only to the neural tissue (Fig. 2) either in the digitations of the neurohypophysis or among the adenohypophyseal cells. No cellular uptake could be visualized either by pituicytes or by glandular cells. In all cases, the silver grains were located over part of the so-called type B fibers whose neurosecretory granules have a diameter of $60-80 \mathrm{~nm}$. In the rostral $\mathrm{NH}$, where there is a clear separation from the $\mathrm{AH}$, the labeled profiles were often located facing the so-called basement membrane (Fig. 3). In the other parts of the gland, they were encountered more randomly either in small nervous tracts or among the different cell types.

Immunocytochemistry. Incubation of pi- 
tuitary Vibratome sections with antibodies against GABA resulted in an important labeling of the $\mathrm{NH}$ and its digitations (Fig. 4). A large tract of Ir fibers entered the $\mathrm{NH}$, crossed the PD, and reached the NIL. From the rostral $\mathrm{NH}$, smaller tracts were seen to invade the rostral (RPD) and proximal (PPD) components of the pars distalis. Isolated individual positive profiles could be detected in all parts of the adenohypophysis $(\mathrm{AH})$.

At the electron microscope level, Ir profiles were also seen to correspond to part of the type B fibers. As for radioautography, the labeling was located in the digitations of the neurohypophyseal tissue, but many positive profiles were encountered in direct contact with secretory cells.

In the rostral $\mathrm{NH}$, positive profiles were observed in direct apposition with pituicytes and on some occasions figures suggesting synaptic-like contacts could be observed (Fig. 5). The Ir profiles were frequently found facing the basement membrane separating the neurohypophysis from the adenohypophysis in a position similar to that described previously for radioautography. However, they were also observed in direct contact with the secretory cells, in particular the prolactin (PRL) cells (Figs. 6 and 7). Although no really clear pictures of synaptic contacts could be observed, slight thickenings of the fiber and PRL cell membranes were detected on some occasions (Fig. 7).

In the PPD, both gonadotrophs (GTH) and growth hormone (GH) cells were frequently found to be in direct contact with the Ir fibers (Figs. 8-11). Occasionally, pictures suggesting possible synaptic-like contacts were observed (Fig. 11).

As shown in Fig. 4, numerous GABApositive fibers reached the NIL. Electron microscope examination showed that these fibers were located in the nervous tissue (Fig. 12), but also in close apposition with both cell types of the intermediate lobe, the MSH-secreting cells (Fig. 13), and the calcium-sensitive cells.

\section{DISCUSSION}

The present investigation demonstrates by two fundamentally different approaches that the goldfish pituitary receives a massive GABAergic innervation of central origin. Indeed, radioautography is based on the visualization of the cellular uptake of an exogenously applied tracer, while immunocytochemistry reveals the cellular content in an endogenous antigen.

The specificity of $\left[{ }^{3} \mathrm{H}\right] \mathrm{GABA}$ uptake by GABA neurons is largely documented. In vitro studies (Iversen and Johnston, 1971; Martin and Smith, 1972) of the kinetics of GABA accumulation have shown that there are two transport systems of different affinities: one of high affinity $\left(K_{m}\right.$ around $\left.10^{-5}-10^{-6} M\right)$ and another with low affinity $\left(K_{m}\right.$ around $\left.10^{-3}-10^{-4} M\right)$. The highaffinity transport is due to an active uptake most likely involved in the inactivation of neurotransmission (Roskoski, 1978) and thus is specific to GABAergic neurons (Martin, 1976). However, it has been shown that glial cells can take up tritiated GABA with an affinity similar to that of neurons (Schon and Kelly, 1974), but this transport is much slower. Therefore, under the conditions of our study (low concentrations of $\left[{ }^{3} \mathrm{H}\right] \mathrm{GABA}$, short incubation times), we may assume that the uptake of the tracer is selective for GABA neurons. In addition, no cellular uptake, in particular by pituicytes, has been observed. Concerning the radioautographic approach, our results are similar to those obtained by Follénius (1972) demonstrating that GABA terminals, also of type $B$, are present in the rostral neurohypophysis of the stickleback. In addition, we found evidence that this GABAergic innervation is not limited to the rostral NH but occurs in other parts of the pituitary as well.

The validity of using GABA antibodies to study the distribution of GABA within the central nervous system is now largely documented (Ottersen and Storm-Mathisen, 1984; Seguela et al., 1984, 1985; 

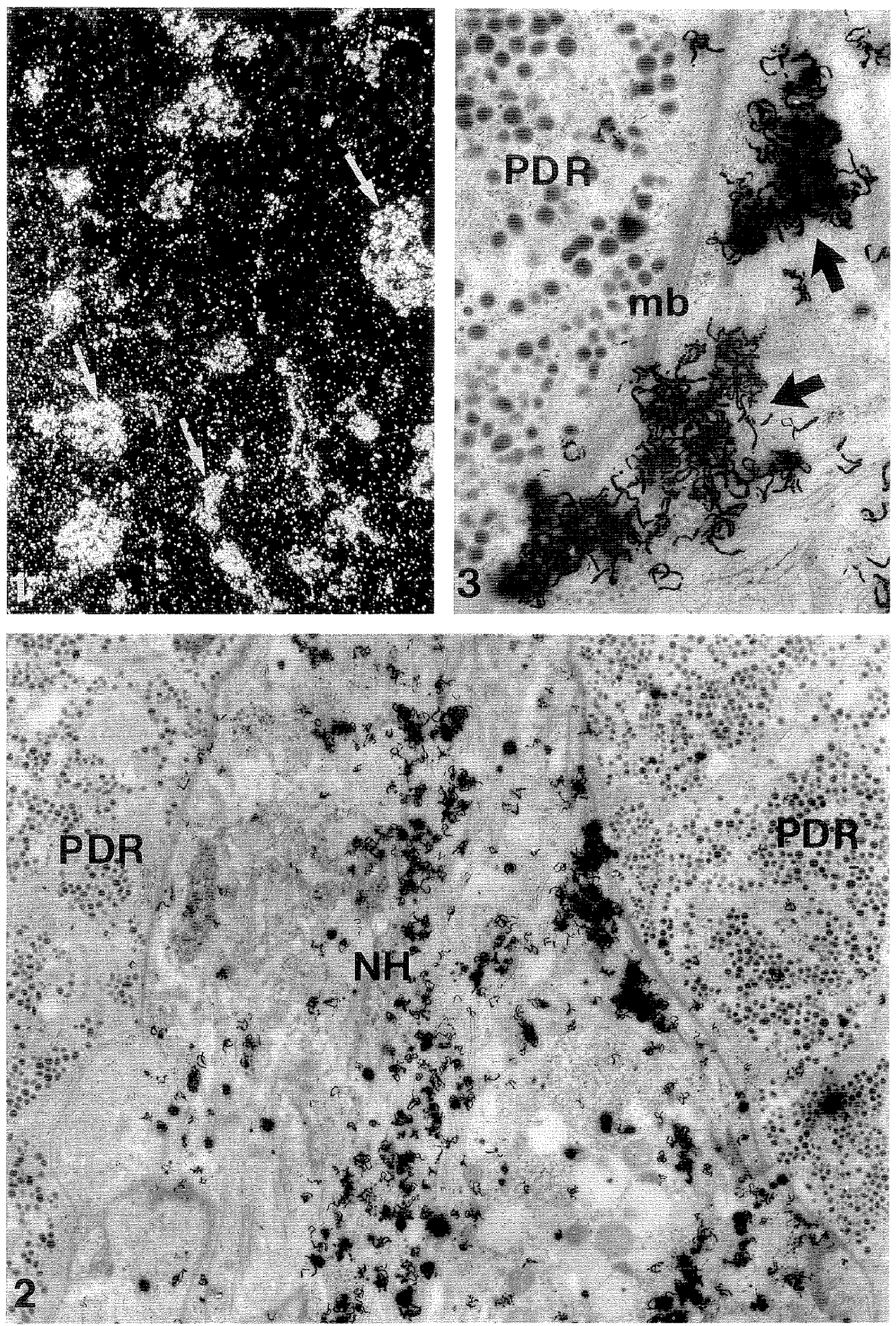

FIG. 1. Semithin section at the level of the pars distalis under dark-field illumination showing the important uptake of $\left[{ }^{3} \mathrm{H}\right] \mathrm{GABA}$ within the digitations of the neurohypophysis (arrows). $\times 435$.

FIG. 2. At the electron microscope level, the tracer appears accumulated over the neurohypophysial tissue $(\mathrm{NH})$ only, here at the level of the rostral pars distalis (PDR). $\times 6700$.

FIG. 3. High-power view showing type B endings (arrows) upon the basement membrane (mb) facing the rostral pars distalis (PDR). $\times 14500$. 

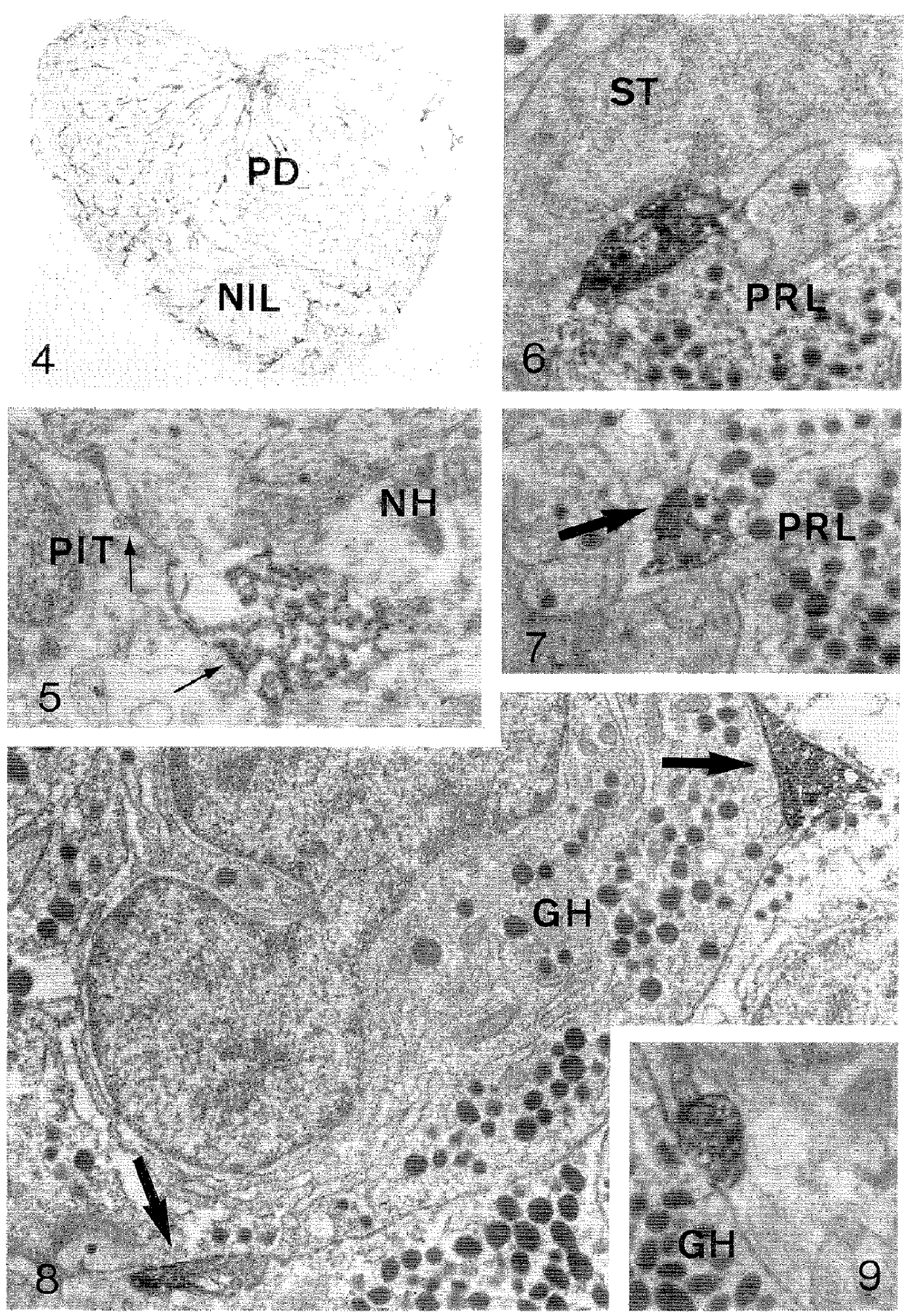

FIG. 4. Transverse Vibratome section $(40 \mu \mathrm{m})$. GABA-positive profiles invade all parts of the pituitary. PD, pars distalis; NIL, neurointermediate lobe. $\times 30$.

FIG. 5. In the neurohypophysis ( $\mathrm{NH}$ ), positive and negative profiles establishing synaptoid contacts (arrows) on a pituicyte (PIT), $\times 23600$.

FIGs. 6 AND 7. In the rostral pars distalis, type B positive fibers were frequently observed in direct contact with prolactin cells (PRL). On some occasions, slight membrane thickenings (arrow) could suggest synaptic-like contacts. ST, stellate cell. Fig. 6: $\times 17,000 ;$ Fig. 7: $\times 19,000$.

FIGS. 8 AND 9. GABA-immunoreactive profiles were often observed in close apposition with the growth hormone cells $(\mathrm{GH})$. Fig. 8: $\times 14300$; Fig. 9: $\times 18000$. 

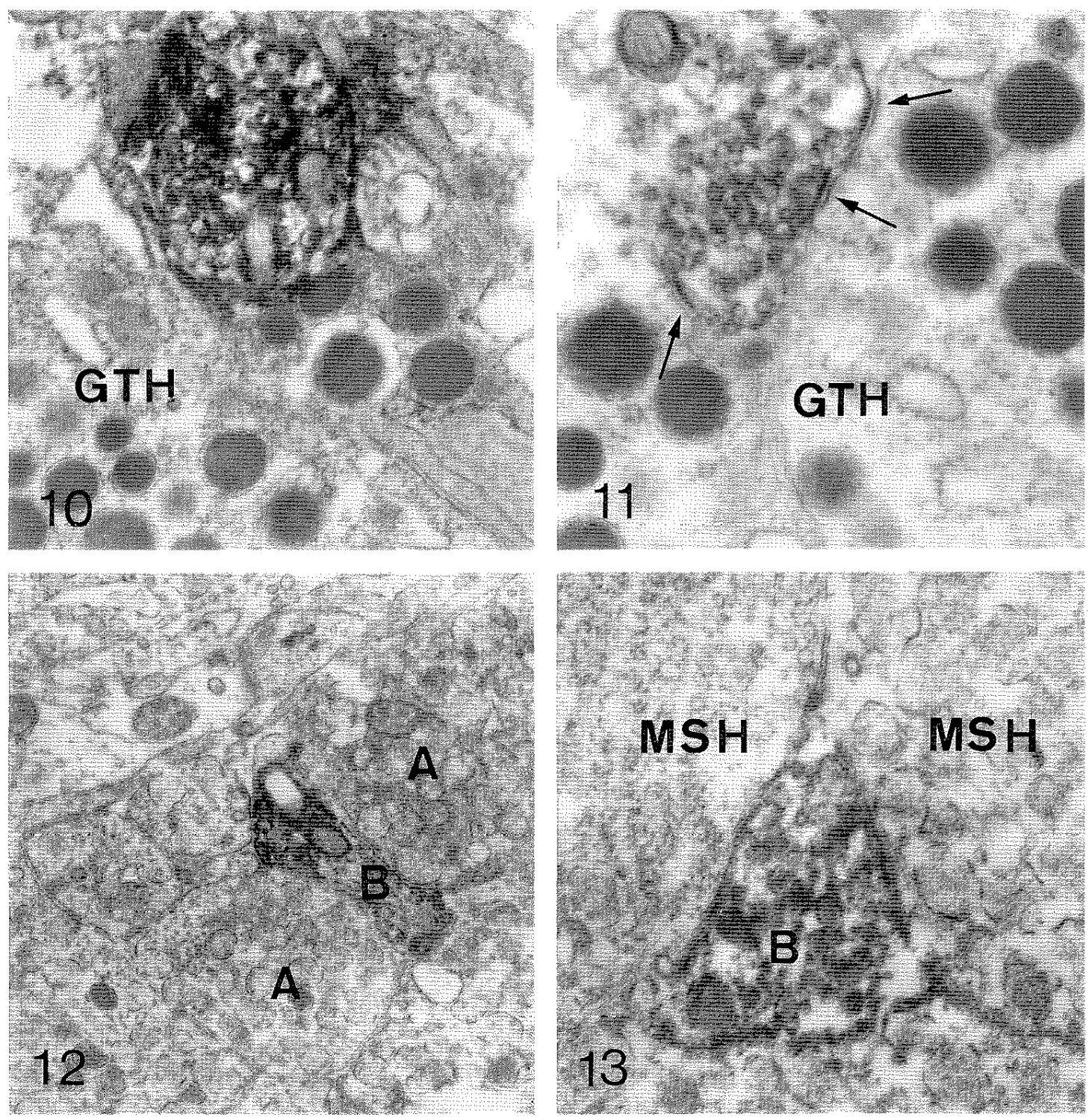

FIGS, 10 AND 11. GABA-positive fibers in direct contact with the gonadotrophs (GTH). In some cases, membrane thickenings (arrows) suggest synaptoid contacts. Figs. 10: $\times 23700$; Fig. 11: $\times 35500$.

FIGS. 12 AND 13. In the neurointermediate lobe, type B positive profiles were observed either in the nervous tissue (Fig. 12) or in direct contact with the secretory cells (Fig. 13). A, type A fiber; MSH, melanotrophs. Fig. 12: $\times 18700$; Fig. 13: $\times 17500$.

Gamrani et al., 1986; Onteniente et al. 1987; Kah et al., 1987; Rabhi et al., 1987). The antiserum used in this study, prepared against GABA coupled to a carrier protein with glutaraldehyde, has been shown by in vitro competitions and by immunocytochemical controls to be highly specific for GABA (Seguela et al., 1984, 1985; Gamrani et al., 1986; Onteniente et al., 1987; Rabhi et al., 1987; Kah et al., 1987). In addition, the good correlation between radioautography and immunocytochemistry strongly supports the conclusion that type B GABA fibers have a widespread distribution in the goldfish pituitary. Such an innervation is most likely present in other teleosts according to the data obtained in the rostral NH by Follénius (1972) or to our 
own observations in the rainbow trout $(\mathrm{F}$. Gonnet and O. Kah, unpublished data). From a quantitative point of view, despite underestimation of the number of labeled profiles due to the limitations of the two techniques (diffusion of the tracer, penetration of antibodies), this innervation appears to be important. With the two methods used in this study, positive endings were very easy to find at the electron microscope level if compared, for instance, with the number, in the same condition, of dopaminergic fibers (Kah et al., 1984, 1986). Nevertheless, the number of Ir profiles was inferior to that of fibers labeled by radioautography, most likely because of the reduced penetration of immunoreagents into the glutaraldehyde-fixed tissue. This abundance of GABA-containing profiles in the goldfish pituitary led us to raise the question of a possible coexistence of GABA with other neurohormones within the same fiber. Experiments in this direction are in progress in our laboratory.

Another point of interest concerns the possible existence of synaptic contacts between GABA endings and the secretory cells. Using conventional electron microscopy, synaptoid contacts between type B fibers and adenohypophyseal cells are occasionally observed but they are weakly differentiated (Kaul and Vollrath, 1974). Nevertheless the observation in the present study of accumulations of small clear vesicles facing membrane thickenings could suggest that GABA type B fibers may establish synaptoid contacts with pituicytes or secretory cells, further allowing the assumption that GABA influences their activity.

From a comparative point of view, it is interesting to mention that this GABAergic innervation is very similar to that demonstrated in other vertebrates. Indeed, using GABA and GAD immunocytochemistry a direct GABA innervation was demonstrated in the intermediate and posterior lobes of Xenopus (Verburg-Van Kemenade et al., 1986), rat (Oertel et al., 1982; Vincent et al., 1982; Tappaz et al., 1983; Kah et al., 1987) and mice (Stoeckel et al., 1985; Rabhi et al., 1987). In mammals, a rich innervation of the external layer of the median eminence has also been described following GABA or GAD immunocytochemistry (Vincent et al., 1982; Tappaz et al., 1983; Berod et al., 1984; Stoeckel et al., 1985; Rahbi et al., 1987; Kah et al., 1987) and radioautography (Tappaz et al., 1980). According to these authors, such terminals, frequently observed to surround the capillaries of the primary plexus, are ideally placed for releasing GABA in the portal blood. Supporting this assumption, GABA has been measured in the portal circulation (Mulchahey and Neill, 1982; Gudelsky et al., 1983) and in the anterior lobe of the pituitary (Racagni et al., 1979). Furthermore, GABA transaminase is also present in the anterior pituitary (Racagni et al., 1979). Most likely, the GABAergic innervation of the median eminence in mammals is the functional equivalent of that of the pars distalis in teleosts which lack the hypothalamo-hypophyseal portal system (Ball, 1981). From this homology, we may presume that this neuroanatomical feature is phylogenetically ancient and was already developed in early gnathostomes and that the functions, largely unknown, carried out by GABA fibers in the pituitary of teleosts are similar to those now well documented in mammals.

In the rat pituitary, high-affinity receptors for GABA have been reported (Grandison and Guidotti, 1979; Anderson and Mitchell, 1986a,b) and could mediate the diverse effects of GABA on the functions of the anterior and intermediate lobes. Indeed, a number of studies have shown that GABA acts on the secretion of prolactin (Pass and Ondo, 1977; Vijayan and McCann 1978; Locatelli et al., 1979; Racagni et al., 1979, 1984), growth hormone (Anderson and Mitchell, 1986a), thyrotrophin (Jordan et al., 1983), lutein- 
izing hormone (Ondo, 1974; Vijayan and McCann, 1978; Anderson and Mitchell, 1986a), and corticotrophin (Anderson and Mitchell, 1986a). In the intermediate lobe, a dual population of receptors has been described (Demeneix et al., 1984) and it is known that GABA regulates MSH release by affecting the electrical properties of the cells (Taraskevitch and Douglas, 1982; Tomiko et al., 1983). A similar effect of GABA on MSH secretion has been recently reported in Xenopus (Verburg-Van Kemenade et al., 1986).

In teleosts, the role of GABA on pituitary functions is poorly documented. In the carp, GABA was shown to inhibit the cortisol increase associated with stress (Follénius, 1977) and to inhibit the release of prolactin (F. Gonnet and P. Prunet, personal communication). Preliminary in vitro experiments in our laboratory suggest that GABA also influences other pituitary functions in goldfish.

\section{REFERENCES}

Anderson, R. A., and Mitchell, R. (1986a). Effects of $\gamma$-aminobutyric acid receptor agonists on the secretion of growth hormone, luteinizing hormone, adrenocorticotrophic hormone and thyroid-stimulating hormone from the rat pituitary gland in vitro. J. Endocrinol. 108, 1-8.

Anderson, R. A., and Mitchell, R. (1986b). Distribution of GABA binding site subtypes in rat pituitary gland. Brain Res. 365, 78-84.

Ball, J. N. (1981). Hypothalamic control of the pars distalis in fishes, amphibians, and reptiles. Gen. Comp. Endocrinol. 44, 135-170.

Berod, A., Chat, M., Paut, L., and Tappaz, M. (1984). Catecholaminergic and GABAergic anatomical relationship in the rat substantia nigra, locus coeruleus, and hypothalamic median eminence: Immunocytochemical visualisation of biosynthetic enzymes on serial semithin plastic-embedded sections. J. Histochem. Cytochem. 32, 1331-1338.

Demeneix, B. A., Desaulles, E., Feltz, P., and Loeffler, J. P. (1984). Dual population of $\mathrm{GABA}_{\mathrm{a}}$ and $\mathrm{GABA}_{\mathrm{b}}$ receptors in rat pars intermedia demonstrated by release of alpha MSH caused by barium ions, Brit. J. Pharmacol. 82, 183-190.

Follénius, E. (1972). Intégration sélective du GABA- ${ }^{3} \mathrm{H}$ dans la neurohypophyse du poisson téléostéen Gasterosteus aculeatus L. Etude ra- dioautographique. C. R. Acad. Sci. 275, $1435-1438$.

Follénius, E. (1977). Inhibition de la fonction corticotrope par l'administration de GABA chez la Carpe (Cyprinus carpio L.). C. R. Acad. Sci. 285, $1435-1438$.

Gamrani, H., Onteniente, B., Seguela, P., Geffard, M., and Calas, A. (1986), $\gamma$-Aminobutyric acidimmunoreactivity in the rat hippocampus: A light and electron microscopic study with anti-GABA antibodies. Brain Res. 364, 30-38.

Grandison, L., and Guidotti, A. (1979). $\gamma$-Aminobutyric acid receptor function in rat anterior pituitary: Evidence for control of prolactin release. Endocrinology 105, 754-759.

Gudelsky, G. A., Apud, J. A., Masotto, C., Locatelli, V., Cocchi, D., Racagni, G., and Müller, E. E. (1983). Ethanolamine- $O$-sulfate enhances $\gamma$-aminobutyric acid secretion into hypophyseal portal blood and lowers serum prolactin concentrations. Neuroendocrinology 37, 397-399.

Iversen, L. L., and Johnston, G. A. R. (1971). GABA uptake in rat central nervous system: Comparison of uptake in slices and homogenates and the effects of some inhibitors. J. Neurochem. 18, 1939-1950.

Jordan, D., Poncet, C., Veisseire, M., and Mornex, R. (1983). Role of GABA in the control of thyrotropin secretion in the rat. Brain Res. 268 , $105-110$

Kah, O., Decavel, C., Rabhi, M., Martinoli, M. G., Dubourg, P., Onteniente, B., Geffard, M., and Calas, A. (1987). GABAergic innervation of the median eminence-pituitary complex: A comparative immunocytochemical study in mammals and fish. Gen. Comp. Endocrinol. (Abstract), in press.

Kah, O., Dubourg, P., Chambolle, P., and Calas, A. (1984). Ultrastructural identification of catecholaminergic fibers in the goldfish pituitary. Cell Tissue Res. 238, 621-626.

Kah, O., Dubourg, P., Onteniente, B., Geffard, M., and Calas, A. (1986). The dopaminergic innervation of the goldfish pituitary. Cell Tissue Res. 244, $577-582$.

Kaul, S., and Vollrath, L. (1974). The goldfish pituitary II. Innervation. Cell Tissue Res. 154, 231-249.

Locatelli, V., Cocchi, D., Frigerio, C., Betti, R., Krogsgaard-Larsen, P., Racagni, G., and Müller, E. E. (1979). Dual $\gamma$-aminobutyric acid control of prolactin secretion in the rat. Endocrinology 105 , $778-785$.

Martin, D. L. (1976). Carrier-mediated transport and removal of GABA from synaptic regions. In "GABA in Nervous System Functions" (E. Roberts, et al., Eds.), Raven Press, New York.

Martin, D. L., and Smith, A. A. (1972). Ions and the 
transport of GABA by synaptosomes. J. Neurochem. 19, 841-855.

McCann, S. M., Vijayan, E., Negro-Vilar, A., Mizunuma, H., and Mangat, H. (1984). $\gamma$-Aminobutyric acid (GABA), a modulator of anterior pituitary hormone secretion by hypothalamic and pituitary action. Psychoneuroendocrinology 9, 97-106.

Mulchahey, J. J., and Neill, J. D. (1982). $\gamma$-Aminobutyric acid (GABA) levels in hypophyseal stalk plasma of rats. Life Sci. 31, 453-456.

Oertel, W. H., Mugnaini, E., Tappaz, M. L., Weise, V. K., Dahl, A. L., Schmechel, D. E., and Kopin, I. J. (1982). Central GABAergic innervation of neurointermediate pituitary lobe: Biochemical and immunocytochemical study in the rat. Proc. Natl. Acad. Sci. USA 79, 675-679.

Ondo, J. G. (1974). $\gamma$-Aminobutyric acid effects on pituitary gonadotropin secretion. Science 186, $738-739$.

Onteniente, B., Geffard, M., Campistron, G., and Calas, A. (1987). An ultrastructural study of GABA-immunoreactive neurons and terminals in the septum of the rat. J. Neurosci. 7, 48-54.

Ottersen, O. P., and Storm-Mathisen, J. (1984). Neurons containing or accumulating transmitter amino acids. In "Handbook of Chemical Neuroanatomy," Vol. 3, "Classical transmitters and Transmitter receptors in the CNS." (A. Björklund, T. Hökfelt, and M. J. Kuhar, Eds.), Elsevier, Amsterdam/New York.

Pass, K. A., and Ondo, J. G. (1977). The effects of $\gamma$-aminobutyric acid on prolactin and gonadotropin secretion in the unanesthetized rat. Endocrinology 100, 1437-1442.

Rabhi, M., Onteniente, B., Kah, O., Geffard, M., and Calas, A. (1987). Immunocytochemical study of the GABAergic innervation of the mouse pituitary by use of antibodies against $\gamma$-aminobutyric acid (GABA). Cell Tissue Res. 247, 33-40.

Racagni, G., Apud, J. A., Cocchi, D., Locatelli, V., and Müller, E. E. (1982). GABAergic control of anterior pituitary hormone secretion. Life Sci. 31, 823-838.

Racagni, G., Apud, J. A., Cocchi, D., Locatelli, V., Iuliano, E., Casanueva, F, and Müller, E. E. (1984). Regulation of prolactin secretion during suckling: Involvement of the hypothalamo-pituitary GABAergic system. J. Endocrinol. Invest. 7, 481-487.

Racagni, G., Apud, J. A., Locatelli, V., Cocchi, D., Nistico, G., di Giorgio, R. M., and Müller, E. E. (1979). GABA of CNS origin in the rat anterior pituitary inhibits prolactin secretion. Nature (London) 281, 575-578.

Roskoski, R. (1978). Net uptake of L-glutamate and GABA by high affinity synaptosomal transport systems. $J$. Neurochem. 31, 493-4.98.
Schon, F., and Kelly, J. S. (1974). The characterization of $\left[{ }^{3} \mathrm{H}\right] \mathrm{GABA}$ uptake by satellite glial cells of rat sensory ganglia. Brain Res. 66, 289-300.

Seguela, P., Gamrani, H., Geffard, M., Calas, A., and Le Moal, M. (1985). Ultrastructural immunocytochemistry of $\gamma$-aminobutyrate in the cerebral and cerebellar cortex of the rat. Neuroscience 16 , $865-874$.

Seguela, P., Geffard, M., Buijs, R. M., and Le Moal, M. (1984). Antibodies against $\gamma$-aminobutyric acid: Specificity studies and immunocytochemical results. Proc. Natl. Acad. Sci. USA 81, 3888-3892.

Stoeckel, M. E., Tappaz, M., Hindelang, C., Seweryn, C., and Porte, A. (1985). Opposite effects of monosodium glutamate on the dopaminergic and GABAergic innervations of the median eminence and the intermediate lobe in the mouse. Neurosci. Lett. 56, 249-255.

Tappaz, M. L. (1984). GABA and anterior pituitary function: Anatomical data. Psychoneuroendocrinology 9, 85-94.

Tappaz, M. L., Aguera, M., Belin, M. F., and Pujol, J. F. (1980). Autoradiography of GABA in the hypothalamic median eminence. Brain Res. 186, 379-391.

Tappaz, M. L., Wassef, M., Oertel, W. H., Paut, L., and Pujol, J. F. (1983). Light and electron-microscopic immunocytochemistry of glutamic acid decarboxylase (GAD) in the basal hypothalamus: Morphological evidence for neuroendocrine $\gamma$ aminobutyrate (GABA). Neuroscience 9, $271-287$.

Taraskevich, P. S., and Douglas, W. W. (1982). GABA directly affects electrophysiological properties of pituitary pars intermedia cells. Nature (London) 299, 733-734.

Tomiko, S. A., Taraskevich, P. S., and Douglas, W. W. (1983). GABA acts directly on cells of pituitary pars intermedia to alter hormone output. Nature (London) 301, 706-707.

Verburg-Van Kemenade, B. M. L., Tappaz, M., Paut, L., and Jenks, B. G. (1986). GABAergic regulation of melanocyte-stimulating hormone secretion from the pars intermedia of Xenopus laevis: Immunocytochemical and physiological evidence. Endocrinology 118, 260-267.

Vijayan, E., and McCann, S. M. (1978). The effects of intraventricular injection of $\gamma$-aminobutyric acid (GABA) on prolactin and gonadotropin release in conscious female rats. Brain Res. 155, 35-43.

Vincent, S. R., Hökfelt, T., and Wu, J. Y. (1982). GABA neuron systems in hypothalamus and the pituitary gland. Immunohistochemical demonstration using antibodies against glutamate decarboxylase. Neuroendocrinology 34, 117-125. 